\title{
Anak Berkebutuhan Khusus (ABK) Bukan Sampah dan Musibah di Sekolah Penyelenggara Pendidikan Inklusif (SPPI)
}

\author{
Rusmiyati \\ Dinas Pemuda dan Olahraga Kabupaten Kulonprogo \\ email: rusmicilik@gmail.com
}

\begin{abstract}
Inclusion schools provide opportunities to all students of various backgrounds and conditions within a school system and try to discover and develop the potential of multiple students. In developing the potential of students is not only applied to the students special need but also not special need. For the purposes of developing inclusive education teaching, the special needs of learners need to identify and assess the benefits and constraints, as well as the needs of learners. In its capacity as an educator, academic assessment is the main task and function of the teacher. Therefore, teachers can do an academic assessment. But for other assessments such as medical assessment, psychological, of course must be done by professionals who competence in the field.

The curriculum needed for learners with special needs is determined from the assessment results, whether a learner requires modification of the Learning Program Design (RPP) or Individual Learning Program (PPI). Curriculum development in inclusive settings includes duplication, modification, substitution and omission. Teachers in particular schools of inclusion should be provided with knowledge of inclusiveness for children with special needs. Sehinggan ABK can get optimal service.
\end{abstract}

Keyword: Inclusion education, disability

\begin{abstract}
Abstrak
Sekolah inklusi memberikan kesempatan kepada semua siswa berbagai latar belakang dan kondisi dalam satu sistem sekolah dan mencoba untuk menemukan dan mengembangkan potensi siswa yang majemuk. Dalam mengembangkan potensi siswa tidak hanya diterapkan pada siswa special need tetapi juga yang bukan special need. Untuk keperluan pengembangan pengajaran pendidikan inklusi, kebutuhan khusus peserta didik perlu dilakukan identifikasi dan assessment keunggulan dan hambatan, serta kebutuhan peserta didik. Dalam kapasitas sebagai pendidik, asessment akademik merupakan tugas dan fungsi pokok dari guru. Oleh karena itu, guru dapat melakukan assessment akademik. Namun untuk assessment lainnya seperti assessment medis, psikologik, tentunya harus dilakukan oleh profesional yang kompetensi di bidang tersebut.

Kurikulum yang dibutuhkan bagi peserta didik berkebutuhan khusus ditentukan dari hasil assessment, apakah seorang peserta didik membutuhkan modifikasi Rancangan Program Pembelajaran (RPP) atau Program Pembelajaran Individual (PPI). Pengembangan kurikulum dalam setting inklusif meliputi duplikasi, modifikasi, substitusi dan omisi. Guru-guru di sekoah inklusi khususnya harus dibekali pengetahuan tentang keinklusian bagi anak berkebutuhan khusus. Sehinggan ABK bisa mendapatkan pelayanan yang optimal.
\end{abstract}

Kata kunci: Pendidikan Inkluasi, berkebutuhan khusus

LITERASI, Volume VIII, No. $22017 \mid 119$ 


\section{PENDAHULUAN}

Kelahiran anak merupakan kebahagiaan tersendiri bagi kedua orang tuanya bahkan keluarganya. Setiap anak hadir dengan keunikannya masing-masing baik kekurangan maupun kelebihan-kelebihannya. Gambaran umum itu jika anak tersebut dilahirkan dalam kondisi normal. Anak-anak yang berhasil secara akademik dan berprestasi dalam bidang pendidikan maka diberi label mereka anak-anak yang cerdas. Anak-anak yang memiliki masalah dalam emosi, perilaku, malas, dan tidak memperhatikan guru ketika menerima pelajaran maka langsung mereka dijusment sebagai anak nakal, anak bodoh dan berbagai atribut negatif yag diberikan oleh lingkungan. Para orang tua kadang merasa malu memiliki anak yang berbeda dengan anak pada umumnya. Anak-anak mereka dilarang bermain dengan teman-temannya. Anak yang sebenarnya mengalami hambatan mental, mereka menjadi korban kemarahan oleh para orang tua mereka karena belajarnya banyak mengalami hambatan. Faktor eksplorasi orang tua pada anaknya akan memberikan andil besar dalam perilaku dan akademik yang kurang menuntungkan. Mereka yang mengalami hambatan tersebut menjadi terpuruk tak berdaya karena egergi negatif yang menerpanya. Akibatnya mereka mendapatkan tempat yang kurang menguntungkan.

Undang-Undang Dasar 1945 pasal 31 menjelaskan bahwa setiap warga negara berhak mendapatkan pendidikan. Makna dari amanat pasal 31 tersebut adalah bahwa setiap anak yang "normal" ataupun yang mengalami hambatan memiliki kesempatan yang sama dalam hal pendidikan. Namun juga tidak bisa dipungkiri karena kekurangpahaman orang tua, guru, dan masyarakat kehadiran mereka dianggap sebagai sampah ataupun musibah sehingga mereka merasa tersisih ataupun terasingkan. Sebagai implementasi dari UUD 1945 pasal 31 tersebut pemerintah mengatur juga dalam Undang-Undang sistem Pendidikan Nasional tahun 2003(2003: 21) yantu dengan membuka pendidikan khusus dan layanan khusus.

Semakin maju dunia pendidikan, maka pemerintah juga memberikan perhatian dengan diterbitkannya Permendiknas nomor 70 tahun 2009 yaitu tentang "Pendidikan Inklusif bagi peserta didik yang memiliki kelainan dan potendi kecerdasan dan/atau bakat istimewa". Peserta didik yang memiliki kelainan fisik, emosional, mental, sosial, dan/atau memiliki potensi kecerdasan dan/atau bakat istimewa perlu mendapatkan layanan pendidikan yang sesuai dengan kebutuhan dan hak asasinya. Mereka ada wadahnya yaitu sekolah inklusif.

Dilihat dari tujuannya sekolah inklusi memberikan kesempatan kepada semua siswa berbagai latar belakang dan kondisi dalam satu sistem sekolah dan mencoba untuk menemukan dan mengembangkan potensi siswa yang majemuk tersebut. Dalam mengembangkan potensi siswa tidak hanya diterapkan pada siswa special need tetapi juga yang bukan special need.

Pada dasarnya setiap siswa mempunyai potensi. Hanya kadang yang menjadi masalah adalah sekolah kurang jeli melihat potensi tiaptiap siswa dan tidak ada program individual untuk mengembangkan potensi masing-masing siswa. Dalam multiple inteligences oleh Howard Gardner yang dikutip Asri Budingsih, dijelaskan bahwa kecerdasan/potensi seseorang tidak hanya bertumpu pada kecerdasn intelektual saja, tetapi ada banyak kecerdasan yang lain. Macam kecerdasan tersebut adalah kecerdasan matematis yaitu berpikir dengan penalaran, mendudukkan masalah secara logis, dan kemampuan matematis. Ada kecerdasan linguistik verbal yaitu kemahiran dalam berbahasa untuk berbicara, membaca, menulis, menghubungkan dan menafsirkan. Ada juga kecerdasan musikal ritmik misalnya menyanyi, irama, melodi, dan alat musik. Ada kecerdasan interpersonal yaitu keterampilan manusia dalam berinteraksi dan berkomunikasi dengan orang lain misalnya dalam organisasi, memimpin, berpidato dan bersosialisasi.. Seseorang yang pandai menari, berolah raga, bermain drama merupakan merupakan seseorang yang memiliki kecerdasan kinestetik. Ada juga seseorang yang memiliki kecerdasan spscial visual misalnya seorang desainer, illustrator, pelukis. Selain 
itu ada kecerdasan naturalis dan intraperponal. Setiap manusia pasti memiliki kedelapan kecerdasan tersebut walaupun kuat di satu sisi dan lemah disisi lain.

Implementasi dari Permendiknas nomor 70 tahun 2009 tersebut banyak provinsi dan kabupaten dengan keputusan gubernur atau bupati menyatakan sebagai provinsi atau kabupaten inklusif. Sekolah sekolah pun dari PAUD/TK sampai dengan jenjang pendidikan menengah banyak yang sudah ditetapkan sebagai sekolah inklusif. Mestinya sekolah tersebut aksesibilitasnya sudah inklusif dan tenaga pendidik dan kependidikannya sudah semua memahami tentang pelayanan bagi anak berkebutuhan khusus.

Untuk keperluan pengembangan pengajaran pendidikan inklusf, kebutuhan khusus peserta didik perlu dilakukan identifikasi dan asesmen keunggulan, hambatan serta kebutuhan peserta didik. Dalam kapasitas sebagai pendidik, asesmen akademik merupakan tugas dan fungsi pokok dari guru. Oleh karena itu, guru dapat melakukan asesmen akademik. Namun untuk asesmen lainnya seperti asesmen medis, psikologik, tentunya harus dilakukan oleh profesional yang kompetensi di bidang tersebut.

Berdasarkan pengamatan langsung dan laporan dari kepala sekolah dan guru-guru yang dikunjungi ataupun ketika memberi materi tentang pendidikan inklusif penulis memprediksi dan menemukan para orang tua dan guru banyak yang belum memahami tentang karakeristik anak berkebutuhan khusus (ABK), cara memberi bantuan' stategi pembelajaran dan kurikulum yang digunakan di sekolah inklusif. Guru belum mengetahui cara melakukan identifikasi, asesmen dan membuat profil peserta didik berkebutuhan khusus. Akhirnya, siswa berkebutuhan khusus dapat tertekan dan tersingkirkan. Para guru tertantang untuk menemukan mutiara-mutiara dari kedelapan kecerdaan tersebut dari para difabel Oleh karena itu, dalam tulisan ini akan penulis uraikan tentang karakteristik ABK dan cara memberikan bantuan, stategi pembelajaran dan kurikulum yang digunakan. Harapannya sekolah inklusif dapat menumbuhkembangkan anak secara optimal, baik bagi anak dengan maupun tanpa berkebutuhan khusus.

\section{Pembahasan Anak Berkebutuhan Khusus (ABK)}

Dalam pembahasan lingkup anak berkbutuhan khusus (ABK) bukan sampah dan musibah terdapat sejumlah hal penting yang perlu diperhatikan. Berbagai hal tersebut dapat dipahami pada pembahasan karakteristik ABK, strategi pembelajaran, dan kurikulum yang digunakan.

\section{Karakteristik Anak Berkebutuhan Khusus}

Ada beberapa pengertian tentang ABK. Haward(2006) ABK adalah anak dengan karakteristik khusus yang berbeda dengan anak pada umumnya. Hallahan \& Kaufman (2003) ABK adalah mereka yang membutuhkan pendidikan khusus dan pelayanan terkait untuk merealisasikan potensinya. Demeris, Child\&Jordan (2007) ABK adalah anak yang memiliki keterbatasan dan keterbatasan tersebut mempengaruhi hidupnya.

UNESCO, ABK adalah anak yang dapat memerlukan pendidikan khusus, yang dapat dilakukan di sekolah khusus ataupun sekolah pada umumnya. Sedangkan Bandi Delphi (2012: 1) menjelaskan bahwa Anak Berkebutuhan Khusus (ABK) merupakan istilah lain untuk menggantikan kata "Anak Luar Biasa (ALB)" yang menandakan adanya kelainan khusus. Ada beberapa jenis anak berkebutuhan khusus dan masing-masing mempunyai karakteristik yang berbeda antara satu dan lainnya.

Jenis-jenis ABK sebagaimana dimaksud dalam Permendiknas nomor 70 tahun 2009 adalah a) tunanetra; $b$ ) tunarungu; c) tunawicara; d) tunagrahita,; e) tunadaksa; f) tuna laras; g) berkesulitan belajar; h) lamban belajar; i) autis; j) memiliki gangguan motorik; k) menjadi korban penyalahgunaan narkoba, obat terlarang, dan zat aditif lainnya; 1) memiliki kelainan lainnya dan $\mathrm{m}$ ) tunaganda. Dalam pembahasn ini tidak semua dibahas, namun yang sering 
dijumpai disekolah-sekolah reguler ataupun sekolah inklusif.

\section{Tunagrahita}

Anak tunagrahita memiliki kemampuan yang signifikan dibawah rata-rata dan disertai dengan ketidakmampuan dalam adaptasi perilaku yang muncul dalam masa perkembangan. Tunagrahita dibedakan dengan tunagrahita ringan, sedang, berat dan sangat berat. Berdasarkan hasil tes IQ atau asesmen tunagrahita ringan memiliki IQ 51-70; sedang (IQ 36-51); berat (IQ 20-35) dan sangat berat (IQ di bawah 20). Hambatan-hambatan yang dialami antara lain suka menghindarkan diri dari orang lain. Terkait dengan kesehatan tingkat pertumbuhan/postur tubuh yang tidak normal. Sebagian dari mereka ada yang mempunyai kelainan penyerta yaitu cerebral palsy

Ciri-ciri khusus yang diimiliki anak tunagrahita adalah perilaku tidak sesuai dengan usia (kekanak-kanakan); sulit memahami hal yang abstrak; daya ingat lemah, sulit mengikuti instruksi yang panjang; sulit mengendalikan emosi, memiliki wajah mirip; nilai semua mata pelajaran di bawah rata-rata. Anak tunagrahita membutuhkan bantuan konsistensi dan berulang dalam belajar; menggunakan media konkrit dan menarik yang dekat dengan kehidupan anak; apabila menerima instruksi, instruksi tersebut yang pendek, jelas, dan bertahap; menggunakan kalimat dan bahasa sederhana, memerlukan pembiasaan,

\section{Tunadaksa}

Tunadaksa adalah kondisi kelainan atau memiliki gangguan pada anggota gerak yang disebabkan oleh kelainan neuro-muskular yang dibawa sejak lahir, sakit atau kecelakaan, termasuk cerebral palsy (CP) amputasi, polio dan lumpuh. Tunadaksa ada yang ringan, sedang ataupun berat.

Dalam pelaksanaan proses pembelajaran, hal-hal yang berkaitan dengan prinsip dan lingkungan harus diperhatikan. Contoh dalam memberikan layanan antara lain: (1) bagi yang menggunakan tongkat/kruk, jangan memegang tangan mereka ketika mereka berjalan; (2) Bagi mereka yang menggunakan kursi roda, sediakan ram atau bidang miring untuk memudahkan mereka bergerak; (30) tawarkan tempat duduk dekat pintu; (4) bila ruang toilet tidak luas, sebaiknya pintu ditarik ke luar,; (5) pasang railing di sepanjang dinding untuk mempermudah bergerak; dan (6) bila bangunan berlantai dua atau lebih sediakan lif, atau ruang kegiatan di lantai bawah.

\section{Kesulitan belajar}

Kesulitan belajar menurut Davit Smit (2009:75) adalah gangguan pada satu atau lebih proses psikologis dasar yang meliputi pemahaman atau penggunaan bahasa lisan atau tulisan yang ditunjukkan dengan kemampuan yang tidak sempurna dalam mendengar, berpikir, berbicara, membaca, menulis, mengeja, atau melaukan perhitungan matematis.

Menurut Kaufman \& Hallalan (2003) jenis hambatan pada anak dengan kesulitan belajar meliputi diskalkulia, disleksia, dan disgrafia. Diskalkulia yaitu kesulitan dalam memahami simbul matematika, konsep, arah dalam berhitung atau terbalik dalam menulis angka atau nilai tempat.Disleksia yaitu kesulitan dalam membaca seperti membaca lompat kata/kalimat/ baris. Sedangkan disgrafia yaitu kesulitan dalam menulis seperti huruf takberbentuk dan tulisan besar-besat. Anak dengan disleksia dan disgrafia menunjukkan beberapa perilaku ucap dan tulis yaitu: (refalsal: ubi menjadi ibu, buku menjadi duku); (substitusi: laut menjadi lauk); (adisi: uang menjadi uwang); (omisi: kayu menjadi kyu, rumah-rumah) dan (sequential memory-kepala menjadi kelapa dan topi menjadi pito)

Tanda-tanda dari disleksia antara lain kesulitan membuat pekerjaan tertulis secara terstruktur, sering tertukar dalam menuliskan huruf kesulitan memahami kalimat yang dibaca atau didengar. Kesalahan umum yang dilakukan siswa diskalkulia adalah kurangnya pemahaman tentang simbul, nilai tempat, penggunaan proses yang keliruan dan jawaban serampangan. Sedangkan ciri-ciri disgrafia 
misalnya inkonsistansi bentuk huruf dan tulisannya, sulit memegang pensil atau pulpen dengan mantap, berbicara pada diri sendiri ketika menulis, kesulitan sekalipun hanya menyalin.

Ada beberapa cara memberikan bantuan pada siswa yang mengalami kesulitan belajar antara lain membutuhkan pengulangan dalam belajar, menggunakan 5 pertanyaan dasar (apa, siapa, di mana, kapan, mengapa), membaca dengan bantuan penggaris agar tidak ada kalimat yang terlewatkan, gunakan buku berpetak untuk menghitung nilai tempat dan panggil nama dan pegang lengan atau bahunya untuk memfokuskan perhatian

\section{Lamban belajar}

Anak yang mengalami masalah daya ingat (memori) ajarkan dengan menggunakan highlighting yaitu menggarisbawahi dengan penanda. Mereka diberi tahu cara memilih tajuk bacaan, kalimat dan istilah kunci unuk digaris bawah atau ditandai dengan highlighter untuk membantu memancing ingatan. Meraka diperbolehkan menggunakan alat bantu misalnya menggunakan daftar ejaan, daftar perkalian, jadwal harian dapat juga didekatkan siswa untuk mengingat jadwal selanjutnya. Biarkan siswa yang mengalami lamban belajar mengambil tahapan yang lebih kecil dalam pengajaran, artinya materi dibagi dalam dua unit atau lebih. Ajarkan siswa lamban belajar dengan berlatih mengulang dan mengingat.

\section{Nakal}

Murid nakal di sekolah tentu bukan sesuatu yang mengherankan. Siswa nakal tersebut sering menimbulkan kebingungan bagi guru. Siswa nakal justru membutuhkan bimbigan, perhatian, serta penangan khusus di antara teman-teman lainnya. Oleh karen itu, perlu dijelaskan mengenai wujud dari kenakalan siswa khususnya yang duduk di bangku sekoah. Ada banyak cara guru dalam mengatasi kenakalan siswanya. Menurut Mappiare dalam Bambang Putranto(2015: 71-78) bahwa dalam menyelesaian kasus siswa, seorang guru harus dapat berperan sebagai pembimbing, pengeloa kelas, dan konselor.

Ada banyak cara guru dalam mengatasi kenakalan siswanya. Beberapa cara tersebut adalah (1) memberikan tanggung jawab, (2) memberikan perhatian, (3) Menciptakan pembelajaran PAKEM,, (4) Membuat peraturan yang jelas di dalam kelas.

\section{Bandel}

Bandel merupakan sifat tidak mau menurut, lepas dari aturan, berbuat sesuai kehendak sendiri, serta tindakan keluar dari aturan-aturan yang telah ditetapkan. Sebagai contoh dari sikap bandel adalah terlambat masuk kelas, memelihara rambut gondrong, tidak memasukkan baju ke dalam celana, enggan menuruti nasehat guru, dan sebagainya. Sikap bandel tersebut merupakan warna asli anak-anak yang ada beberapa kiat menyampaikan materi kepada siswa bandel. Kiat-kiat tersebut misalnya: 1) bersikap terbuka, 2) mau mendengar, 3) membangun sikap positif, 4) mengkaji ulang harapan guru, dan 5) menghargai siswa.

\section{Hiperaktif}

Anak hiperaktif mengalami gangguan pemusatan perhatian dengan hiperaktivitas (GPPH) atau atttention dificit and hyperactivity disorder (ADHD). Siswa hiperaktif hampir memiliki karakter hampir tidak bisa tenang, sering mengganggu orang lain, suka memotong pembicaraan, serta kesulitan dalam memahami pembicaraan guru. Prestasi belajar anak hiperaktif juga kurng maksimal.

Anak hiperaktif mempunyai ciri umum dan ciri khusus. Zafierab menyebutkan beberapa ciri tersebut seperti dirangkum pada tabel 1 .

Anak hiperaktif membutuhkan perhatian dan penangan tersendiri. Penangan pembelajaran tidak bisa disamakan dengan anak pada umumnya. Secara umum terapi pada anak hiperaktif dapat dilakukan sebagaimana siswa dengan gangguan autisme. Pertama, menambah pengetahuan tentang hiperaktivitas. Kedua, mengenali kelebihan dan bakat anak; 
Tabel 1 Ciri umum dan khusus anak hiperaktif

\begin{tabular}{|c|c|c|}
\hline \multicolumn{2}{|r|}{ Ciri-ciri Umum } & Ciri-ciri Khusus \\
\hline & Tidak memperhatikan & 1. Sering menggeliat atau menggerakkan tangan dan kaki \\
\hline & Mempunyai energi berlebih & ketika duduk \\
\hline & Impulsif yaitu bertindak tanpa berpikir & 2. Sering meninggalkan tempat duduk \\
\hline & Menentang & 3. Sering berlari-lari atau memanjat \\
\hline & Destruktif atau merusak & 4. Tidak melakukan kegiatan dengan tenang \\
\hline & Tidak memilikin tujuan & 5. Selalu bergerak \\
\hline & Tidak sabar dan usil & 6. Terlalu banyak bicara \\
\hline 8. & Memeiliki kecerdaan rendah & 7. Sulit menunggu giliran \\
\hline 9. & Sering mudah terganggu konsentrasinya & 8. Sering memotong/menyela pembicaraan \\
\hline & $\begin{array}{l}\text { Sering kehilangan benda-benda yang diperlukan } \\
\text { melaksanakan aktivitasnya. }\end{array}$ & 9. Bersikap apatis \\
\hline
\end{tabular}

ketiga, membantu anak bersosialisasi; keempat, menggunakan teknik pengelolaan perilaku; kelima, memberikan ruang gerak yang cukup bagi aktivitas untuk menyalurkan kelebihan energinya; keenam, menerima keterbatasan dan membangun rasa percaya diri dan ketujuh, memberi kesempatan untuk melakukan pengelolaan perilakunya sendiri melalui bimbingan guru.

\section{Autis}

Autis adalah suatu jenis gangguan perkembangan yang kompleks yang meliputi gangguan interaksi sosial, pola komunikasi, minat dan gerakan yang terbatas sehingga perlu penanganan sejak dini. Mujito dkk. Menjelaskan bahwa delapan puluh persen anak autis memiliki IQ dibawah 70. Mereka mungkin menunjukkan hal yang buruk pada hal yang berhubungan dengan bahasa tetapi mereka ada yang menunjukkan hasil yang baik pada kemampuan visual spatial, perkalian empat digit atau memiliki long term memory yang baik. Mereka mungkin mempunyai bakat besar yang tersembunyi.

Autisme bukan untuk dihindari. Mereka perlu perhatian khusus dari keluarga, guru dan lingkungannya. Kebanyakan orang menganggap remeh anak autis, tapi jangan salah bahwa penderita autis banyak yang menjadi sukses dalam hidupnya. Ada pendrita autis yang menjadi pakar dalam bidang sains, matematika, komputer, dan lain-lainnya.

\section{Pengembangan Kurikulum}

Satuan Penyelenggara pendidikan inklusif menggunakan kurikulum yang mengakomodasi kebutuhan dan kemampuan peserta didik sesuai dengan kecerdasan, bakat, minat, dan potensinya. Peserta didik harus mendapatkan yang sesuai dengan tujuan mereka. Penekanan kurikulum yang diberikan difokuskan pada dua hal yaitu kemampuan membaca, menulis, berhitung (calistung), dan keterampilan (Mujito, Harizak, dan Elfindri (2012:225).

MenurutPedoman Umum penyelenggaraan Pendidikan Inklusif (2013: 22-28) alternatif jenis/model kurikulum sekolah inklusif dijabarkan sebagai berikut:

Jenis kurikulum yang digunakan adalah kurikulum standar nasional, kurikulum akomodatif di bawah standar nasional, dan kurikulum akomodatif di atas standar nasional (eskalasi). Model kurikulum yang digunakan adalah (1) duplikasi, (2) modifikasi, (3) subsitusi, (4) omisi.

Kurikulum akomodatif adalah kurikulum standar nasional yang disesuaikan dengan bakat, minat peserta didik berkebutuhan khusus. Pengembangan kurikulum akomodatif dilakukan oleh masing-masing satuan pendidikan penyelenggara pendidikan inklusif. Kurikulum akomodatif ini diterapkan pada empat model yaitu dulikasi, modifikasi, substitusi, dan omisi serta dalam empat komponen yaitu tujuan, isi, proses, dan evaluasi. 


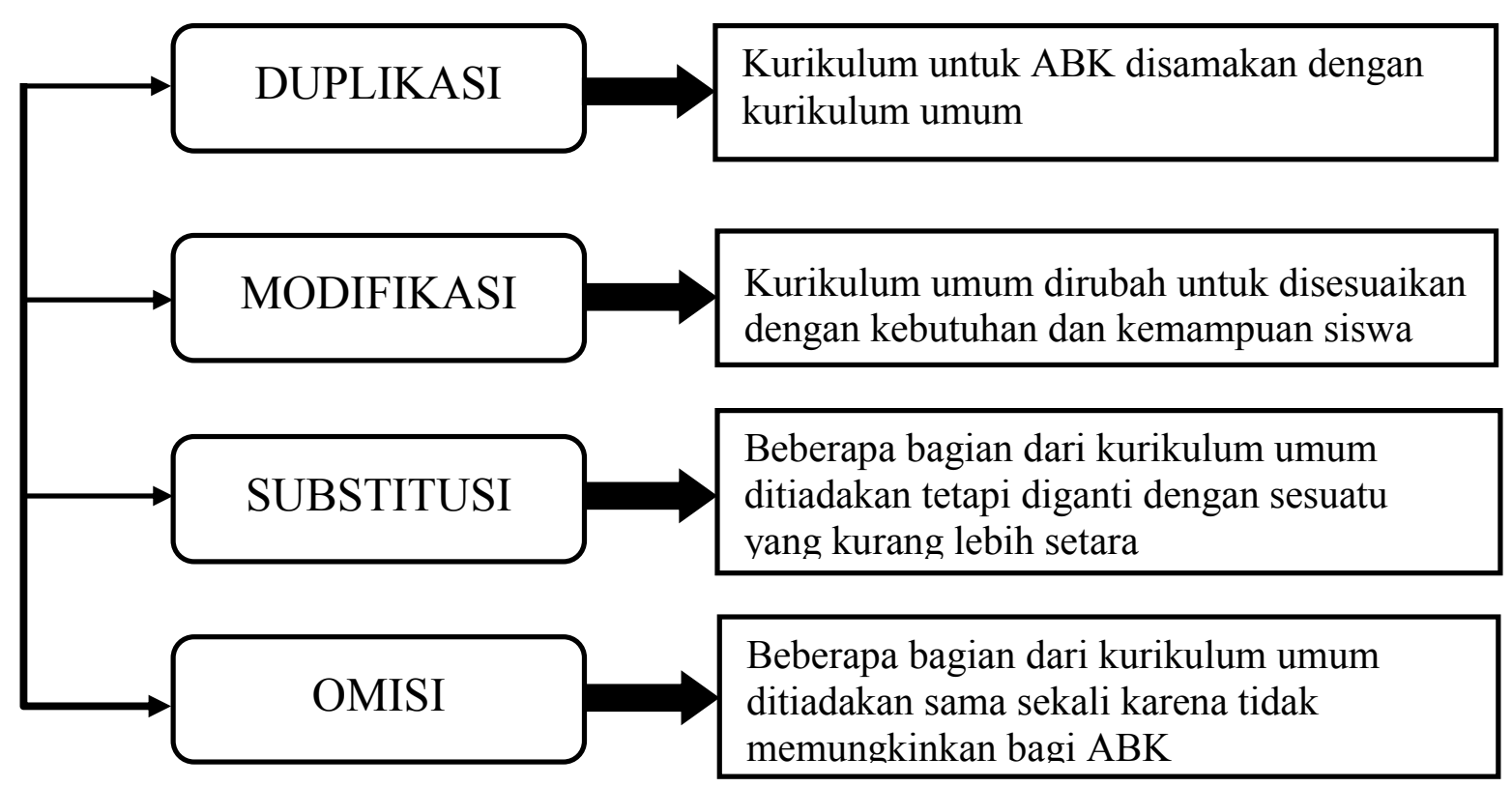

Bagan 1 Model-model Kurikulum dalam Pendidikan Inklusif

1. Model Duplikasi kurikulum adalah mengembangkan dan atau memberlakuan kurikulum bagi peserta diidik berkebutuhan khusus sama atau serupa dengan kurikulum yang digunakan siswa reguler atau siswa pada umumnya. Model duplikasi dapat dierapkan pada empat komponen utama, yaitu tujuan, isi, proses, dan evaluasi.

2. Model modifikasi, merubah untuk disesuaikan dengan kondisi, kebutuhan, dan kemampuan anak berkebutuhan khusus. Modifikasi terjadi pada empat komponen utama pembelajaran, yaitu: tujuan, materi, proses, dan evaluasi.

Sebagai konsekuensi dari tujuan maka siswa ABK memiliki rumusan kompetensi sendiri yang berbeda dengan siswa reguler baik berkaitan dengan standar konpetensi lulusan (SKH), Kompetensi Inti (KI) dan kompetensi dasar (KD) maupun indikatornya. Modifikasi isi berarti siswa ABK mendapatkan materi pembelajaran yang tingkat kedalaman, keluasan, dan kesulitannya berbeda (lebih rendah) dari materi yang diberikan kepada peserta didik reguler. Modifikasi proses dalam kegiatan pembelajaran meliputi metode mengajar, setting/ lingkungan belajar, waktu, media, sumber, dan lain-lain. Sedangkan modifikasi evaluasi berarti perubahan dalam sistem penilaian. Perubahan tersebut bisa berkaitan dengan soal-soal ujian, perubahan dalam waktu evaluasi, teknik, cara evaluasi, atau tempat evaluasi, kriteria kelulusan, sistem kenaikan kelas, bentuk raport ataupun ijazah.

3. Model Substitusi, Subsitusi berarti mengganti. Dalam kaitannya dengan kurikulum maka substitusi berarti mengganti sesuatu yang ada dalam kurikulum umum denga sesuatu yang lain yang sekiranta sepadan dengan yang diganti.

4. Model Omisi. Model kurikulum omisi berarti menghilangkan atau menghapus sesuatu baik sebagia atau keseluruhan dari kurikulu umum karena tidak mungkin diberikan pada ABK.

Bedanya dengan substitusi adalah jika dalam substitu ada materi pengganti yang sebobot, sedangkan dalam omisi tidak ada pengganti.

\section{PENERAPAN MODEL KURIKULUM ADAPTIF}

Dari uraian di atas dapat kita ketahu ada empat kemungkinan model kurikulum adaptif 
Tabel 2.Model kurikulum bagi ABK yang tidak mengalami hambatan kecerdasan

\begin{tabular}{|c|c|c|c|c|c|c|c|c|c|}
\hline \multirow{2}{*}{$\begin{array}{l}\text { Komponen } \\
\text { Model }\end{array}$} & \multicolumn{3}{|c|}{ Tujuan } & \multirow{2}{*}{ Materi } & \multicolumn{2}{|c|}{ Proses } & \multicolumn{3}{|c|}{ Evaluasi } \\
\hline & KI & KD & INDI & & METODE & MEDIA & SOAL & CARA & ALAT \\
\hline Duplikasi & $\checkmark$ & $\checkmark$ & $\checkmark$ & $\checkmark$ & & & $\checkmark$ & & \\
\hline Modifikasi & & & & & $\checkmark$ & $\checkmark$ & & $\checkmark$ & $\checkmark$ \\
\hline Substitusi & & & & $\checkmark$ & & & & & \\
\hline Omisi & & & & & & & & & \\
\hline
\end{tabular}

Tabel 3. Kurikulum bagi ABK yang mengalami hambatan kecerdasan

\begin{tabular}{|c|c|c|c|c|c|c|c|c|c|}
\hline \multirow{2}{*}{$\begin{array}{l}\text { Komponen } \\
\text { Model }\end{array}$} & \multicolumn{3}{|c|}{ Tujuan } & \multirow{2}{*}{ Materi } & \multicolumn{2}{|c|}{ Proses } & \multicolumn{3}{|c|}{ Evaluasi } \\
\hline & KI & KD & INDI & & METODE & MEDIA & SOAL & CARA & ALAT \\
\hline Duplikasi & & & & & & & & & \\
\hline Modifikasi & $\checkmark$ & $\checkmark$ & $\checkmark$ & $\checkmark$ & $\checkmark$ & $\checkmark$ & $\checkmark$ & $\checkmark$ & $\checkmark$ \\
\hline Substitusi & & & & $\checkmark$ & & & & & \\
\hline Omisi & & & & $\checkmark$ & & & & & \\
\hline
\end{tabular}

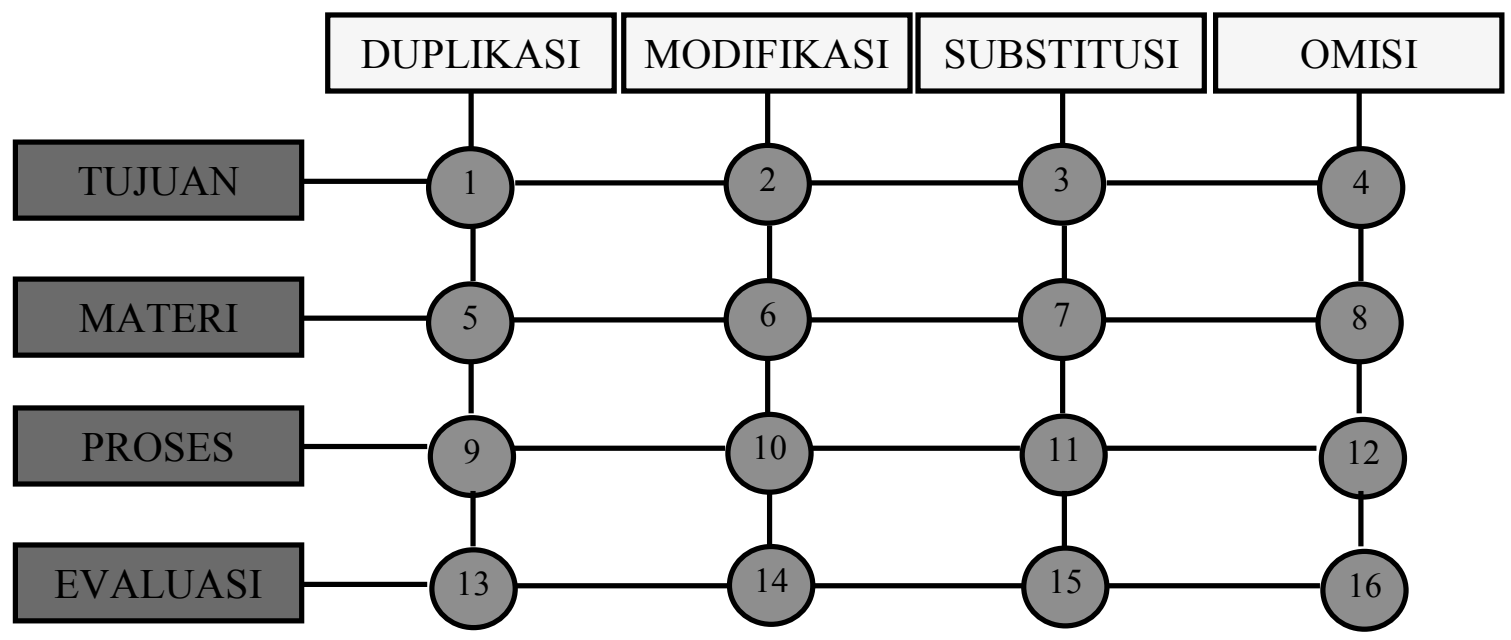

Skema 1. 16 kemungkinan model kurikulum adaptif di sekolah inklusif

yaitu duplikasi, modifikasi, substitusi, dan omisi. Ada empat komponen utama kusikulum yaitu tujuan, materi, proses, dan evaluasi. Mengembangkan kurikulum untuk siswa berkebtuhan khusus pada dasarnya adalah mengawinkan antara model kurikulum dengan komponen kurikulum. Suatu hal yang harus diketahui bahwa proses penyesuaian tidak harus sama untuk semua tujuan, materi, proses, maupun evaluasinya. Proses modifikasi juga tidak sama pada masing-masing jenis kelainan.

Anak berkebutuhan khusus yang tidak mengalami hambatan kecerdasan,misalnya anak tunanetra, tunarungu, tunadaksa membutuhkan sedikit modifikasi dalam pembelajaran. Mereka biasanya lebih banyak membutuhkan modifikasi dalam proses pembelajaran yaitu berkaitan dengan cara dan media yang digunakan dalam menyampaikan informasi. Kecenderungan model kurikulum untuk siswa yang tidak mengalami hambatan kecerdasan dapat dilihat pada tabel 3 dan 4 .

\section{KESIMPULAN}

Dari paparan di atas dapat disimpulkan bawa setiap peserta didik berkebutuhan khusus memiliki hambatan-hambatan tertentu yang berbeda antara satu dengan yang lainnya. Perbedaan hambatan tersebut juga menggambarkan adanya perbedaan kebutuhan layanan pendidikan bagi setiap peserta didik baik yang berkaitan dengan kemampuan atau ketidakmampuan peserta didik secara individual. 
Kurikulum yang dibutuhkan bagi peserta didik berkebutuhan khusus ditentukan dari hasil asesmen, apakah seorang peserta didik membutuhkan modifikasi Rancangan Program Pembelajaran (RPP) atau Program pembelajaran Individual(PPI). Pengembangan kurikulum dalam seting inklusif meliputi dulikasi, modifikasi, substitusi dan omisi. Contoh modifikasi adalah ketika siswa tunanetra (low vision) akan belajar IPS maka bahan ajar harus dibesarkan dan dibraillkan bagi ABK yag buta total. Alat peraga seperti peta harus timbul sehingga dapat diraba. Penerapan kurikulum model substitusi misalnya ABK tunadaksa (tidak punya kaki, lumpuh layu) dalam pelajaran lari, maka perlu dibuatkan materi lain yang dapat diikutinya. Modifikasi untuk siswa lamban belajar.

Guru-guru di sekoah inklusisf khususnya harus dibekali pengetahuan tentang keinklusian bagi anak berkebutuhan khusus. Sehinggan ABK bisa mendapatkan pelayanan yang optimal. Para ABK harapannya bisa mandiri yang akhirnya tidak menjadi sampah dan musibah baik di rumah, di sekoah maupun hidup di suatu daerah.

\section{DAFTAR PUSTAKA}

. (2003). Undang-Undang republik

Indonesia Nomor 20 Tahun 2003 tentang Sistem Pendidikan Nasional. Jakarta: Departemen Pendidikan Nasional.
(2009). Mengajar Anak dengan Disabilitas dalam Setting Inklusif. Bandung: IDPN Indonesia. . (2013). Pedoman Penyelenggaraan Pendidikan Inklusif. Jakarta: Direktorat Pembinaan PKLK Pendidikan Dasar Kkemendikbud.

Bandi Dhelpie. (2012). Pembelajaran Anak Tuna Grahita. Bandung: Refika Aditama.

David Smith.J. (2009). Inklusi Sekolah Ramah untuk semua. Bandung: Nuansa.

Hallahan,D.P, \& Kaufman,J.M. (2003). Exceptional Leaners: Instroduction to Special Education. Virginia: Merrill.

Helen Keller Internasional.(2013). Pendidikan Inklusif Berbasis Sekoah. Jakarta: USAID.

Muhammad Efendi. (2009). Psikopedagosik Anak Berkelainan. Jakarta: Bumi Aksara.

Mujito. (2014). Memahami Pendidikan Khusus dan Layanan Khusus. Yogyakarta: Pustaka Pelajar.

Mujito, Harizal, dan Elfindri. (2012). Pendidikan Inklusif. Jakarta: Baduose Media.

Mujito, Praptono, dan Asep Jiehad. (tt). Pendidikan Anak Autis. Jakarta.

Suanto \& Mujito. (2014). Masa depan Pendidikan Inklusif. Jakarta: Kementerian Pendidikan dan Kebudayaan Direktorat Jendral Pendidikan Dasar 